\title{
Political and Economic Democratization and Its Impact on the Government-Business Relationship in Korea ${ }^{1)}$
}

\author{
Byung-Sun Choi \\ Assistant Professor, Graduate School of Public Administration \\ Seoul National University
}

Under the authoritarian market economy system, Korea has achieved a demonstrably successful economic performance. But its inherent systemic tension and conflict, which had been suppressed under the repressive rule, has since 1987 begun to unravel. A series of political democratization moves are still coming on stream and social demands for economic democratization press for a change in economic policy in the direction of correcting economic and social imbalances. Following the change in the relative political strength among proximate policymakers, the state economic policy-making structure and process is undergoing a significant change, and the existing governmentbusiness relationship, biased generally for big business, has come under siege. The potential impacts of these recent changes on the economy's performance have not yet been fully materialized. It must be heeded, however, by responsible political actors that, when the institutional values of a democratic and pluralistic society are overly valued, they inevitably exact a price in terms of the slackening efficiency and the loss of adaptability to the rapidly changing world economic conditions, as the experiences of the advanced democratic industrial countries, particularly the U.S., show.

\section{Introduction}

One recent interesting subject in comparative political economy has been the governmentbusiness relationship in the politically authoritarian but economically market-driven systems which have demonstrated the remarkable strength of the regime in effecting a relatively

1) The term "economic democratization" is widely used in Korea, but its exact meaning is not clear. Here I will use the term meaning and including the following elements : 1) the amelioration of the concentration of economic power; 2) freer labor movement; 3) the reduction of disparities between income classes, and regions; and 4) the democratization of the economic policy-making process. Economic democratization should, therefore, be distinguished from economic liberalization, which is concerned with the reallocation of government and market functions in the management of economy. Furthermore, as will be shown, economic democratization may pose an obstacle in the progress of economic liberalization. On the difference between the goals of the two sets of economic policies and their potential conflicts, see Hoon Yu and Byung-Sun Choi, "Keumhu Kyǔngjejayulhwaǔi Chuyogwajewa Ch'ujinch'eje Kaesōnbangan (Major Issues of Economic Liberalization Ahead and Schemes for Furthering Its Progress)," Korea Development Institute, December 1987, Chapters 1 and 5. 
high rate of economic growth and fair distribution of incomimé. ${ }^{2)}$ Obviously, fitting well into this classification are the Asian NICs. Among them, Korea and Taiwan have attracted particular attention due in part to their common historical heritage and a seemingly closer resemblance of their management of government-business relations to Japan. ${ }^{3)}$ At the center of this interest is the presumed superiority of Japanese style of management of government-business relations in dealing with many complex contemporary policy issues such as industrial restructuring, environmental protection, and the maintenance of industrial peace.4) Korea and Taiwan have been considered not only to be following but "perfecting" this Japanese style of management of government-business relations. ${ }^{5)}$

The emergence of such authoritarian market economies as Korea and Taiwan and their demonstrably successful economic performance has been a challenge to the orthodox analytic framework of comparative political economy which dichotomizes the world politico-economic system into the totalitarian command-and-control economic systems and the democratic free-enterprise systems, regarding the authoritarian market economies only as hybrids.6) Naturally, research interest has thus been centered on how the strong

2) Some literatures representing this trend are: Chalmers Johnson, MITI and the Japanese Miracle (Stanford University Press, 1982); Peter J. Katzenstein, Small States in World Markets (Ithaca: Cornell University Press, 1985); Louis Turner \& Neil McMullen, The Newly Industrializing Countries: Trade and Adjustment (New York: George Allen \& Unwin, 1982); David Collier (ed.) The New Authoritarianism in Latin America (Princeton: Princeton University Press, 1982); and Peter Evans et al. (eds.), Bringing the State Back In (Cambridge: Cambridge University Press, 1985).

3) Of course, Japanese political system is far more democratic. But it is notable that Johnson characterizes the Japanese political system as "soft authoritarian." See Chalmers Johnson, "Political Institutions and Economic Performance: The Government-Business Relationship in Japan, South Korea and Taiwan," in Robert A. Scalapino et al. (eds.), Asian Economic Development and Future (Berkeley: University of California Press, 1985), pp. 64-65.

4) See Japan Economic Institute of America, “Japan's Industrial Policies," Monograph, Washing. ton, D.C., April 1984, pp.3-6; Ira Magaziner and Robert B. Reich, Minding America's Business (New York: Law \& Business, Inc., 1982), Chapter 26; and Ezra F. Vogel, Japan As Number One (Cambridge, Mass.: Harvard University Press, 1979).

5) Until recently, such analogy has been made only on the meager basis of the superficial fact that Korea and Taiwan have followed the Japanese steps rather closely in terms of their rapid cconomic and export growth. But the following two articles have made significant contributions in furthering our understanding of the similarities and discrepancies of the government-business relations between Japan on the one side and Korea and Taiwan on the other: Chalmers Johnson, "Political Institutions," op. cit., pp. 63-89; and Bruce Cummings, "The Origins and Development of the Northeast Asian Political Economy: Industrial Sectors, Product Cycles, and Political Consequences," in International Organixation (Winter 1984), Vol. 38, No. 1, pp. 1-40.

6) On the grand analysis of the world political-economic systems, see Charles E. Lindblom, Politics and Markets: The World's Political-Economic Systems (New York: Basic Books, 1977). 
economic performance and political disaffection can coexist in these systems and how stable such systems can be. Poor economic performance and constant political tension in many Latin American countries seems to stimulate their curiosity about the secrets of Asian authoritarian market economies even further.

As if such academic interest were a self-fulfilling prophesy, the issue of political development, so far deemphasized and trailing far behind the remarkable economic success in these countries, is coming to the fore. "Political development commensurate with economic development" has now become a cliche in these countries. The political and social tension and conflict inherent in these hybrid systems seems to have already started to betray them selves. Like rapid currents under tranquil surface, social demands for political development has grown such a long period that the pretentious systemic stability seems not to be sustained any longer. Now, under this pressure, both the governments of Taiwan (particularly after the death of Generalissimo Chiang Ching-kuo) and Korea (particulary after the embarkation of the Sixth Republic under Roh Tae Woo) are going to travel an untrodden path toward greater political and economic democratization. Surely, the political pressure calling for such changes and the willingness on the part of political leaders to accommodate this pressure is predicated on the strong positions of their economies, namely strong economic growth trend, accumulating trade surplus, and so on. However, it would be legitimate to ask how the political and economic democratization affect their government-business relationship and how seriously it would damage their economies'performance? This article seeks to address this interesting and important question.

\section{Recent Change Affecting the Government-Business Relationship in Korea ${ }^{\text {? }}$}

In examining the plausible impacts of the recent political and economic democratization on the characteristic aspects of Korea's government-business relationship, I will focus on

7) For important contributions to the understanding of Korea's government-business relationship and the role of Korean government in the economic development process in general, see Leroy P. Jones and Il Sakong, Government, Business, and Entrepreneurship in Economic Development: the Korean Case (Cambridge, Mass.: Harvard University Press, 1980); Edward Mason, et al., The Economic and Social Modernization of the Republic of Korea (Cambridge, Mass.: Harvard University Press, 1980); Youngil Lim, Government Policy and Private Enterprise: Korean Experience in Industrialization (Berkeley: University of California Press, 1981). 
the following institutional and social organizational variables: (1) the state economic policy-making structure; (2) the state control over the financial sector; (3) and labor relations. ${ }^{8)}$

\section{A. State Economic Policy-Making Strueture}

Recently, as the major Constitutional and political changes are instituted and social demands for economic democratization mounted, the state economic policy-making structure are undergoing a significant change. First of all, under the new Constitution of 1987, the National Assembly has greatly strengthened its independence from and enlarged the scope of its authority over the executive branch. It has now secured the authority to scrutinize and review a whole range of government policy actions and their consequences once a year and reflect the results in the deliberation of the budget. In addition, it can invoke its investigation authority, whenever deemed necessary, and as to whatever policy actions and wrongdoings in question. With the principle of check and balance firmly established, and as the three opposition parties, taken together, constitute the majority of the thirteenth National Assembly, the oversight function by the National Assembly has been made unprecedentedly secure and strong.

Second, as moves toward political democratization proceed, other proximate policymakers such as the political parties, press, labor unions, and various sorts of interest groups are mustering their political influence swiftly and intensifying efforts aimed at policy development.9" As the structure of political parties changes from bipartisan to quadruple party system after the National Assembly election in April 1988, each party is

8) In analyzing and comparing government-business relationship in one system with the others, one can use different kinds of variables ranging from historical and cultural factors to external linkages. But it should be noted that recent studies in comparative political economy focus increasingly on structural or institutional variables particularly in explaining divergent economic policy choices among countries in the face of similar policy problems. See Peter A. Hall, Governing the Economy: The Politics of State Intervention in Britain and France(New York: Oxford University Press, 1986) and "Patterns of Economic Policy: An Organizational Approach," in Stephen Bornstein et al. (eds.), The State in Capitalist Europe (London: George Allen \& Unwin, 1984), pp. 21-53; Peter J. Katzenstein (ed.), Between Power and Plenty: Foreign Economic Policies of Advanced Industrial States (Madison: University of Wisconsin Press, 1984); and John H. Goldthorpe (ed.), Order and Conftict in Contemporary Capitalism: Studies in the Political Economy of Western European Nations (Oxford: Clarendon Press, 1984). The selection of structural variables here can be compared to those used by Chalmers Johnson and Peter Hall. See Johnson, "Political Institutions," op. cit., p. 73; and Hall, "Patterns of Economic Policy," op. cit., pp. 23-25.

9) For the definition of proximate policymakers in the democratic system, see Charles E. Lindblom, The Policy-Making Process (Englewood Cliffs, New Jersey: Prentice-Hall, Inc., 1968), Chapter 9 . 
engaging in policy competition partly in an effort to identify itself with particular groups of society more strongly and cement these groups' political support. As the press is given more freedom, new press media are making appearances and compete for audience and public opinion leadership through active and critical reporting. As the government lifted restrictive regulations on labor movement and tends to maintain hands-off policy about labor disputes, labor unions are looking for new stance on labor policy. Convinced about the changing political climate, chaebol groups, generally under the auspices of the Federation of Korea Industries, began to seek favor of the National Assembly, change their posture toward the ruling party (Democratic Justice Party), and turn their eyes to the opposition parties as well. Other interest groups also began to strengthen and diversify channels of their interest representation through the National Assembly and the political parties. ${ }^{10)}$

These changes in the relative political power between the executive branch and legislature, between the ruling and the opposition parties, and between social groups in particular, present a challenge to the existing state economic policy-making structure and process, and have significant implications for the government-business relationship in Korea in the future. These changes indicate that it is neither possible nor desirable to try to maintain the existing economic and social policy framework biased toward big business and the better-off groups of society. Legitimacy of the government policy actionboth in its substantive direction and the policy-making process-starts to turn around a different axis now. As the foremost important economic policy objective, economic and social equity and balanced economic development seems to take precedence over rapid economic growth. The economic policy-making process seems no longer to remain in the stronghold of the Presidency and in the hands of a limited number of technocrats who have demonstrated the high degree of political attuning and strategic managerial capabilities. ${ }^{11)}$ Now the process needs greater openness and the economic policy-making power needs to be shared by a greater number of proximate policymakers.

10) See Byŏng Yǒng Ahn, “Ch’aejewingiǔi Keukbokgwa Chŏngch’ aekgyǒljongui Soaeshin (Overcoming the systemic crisis and innovating the policy-making process)," paper presented to the International Conference on Public Administration for the Mature Democratic Society, August 24, 1988, pp. 8-20.

11) For the illustrations of the strategic management of political and economic changes by the high-level technocrats, particularly surrounding the EPB, see Choi, "Institutionalizing A Liberal Economic Order in Korea: The Strategic Management of Economic Change," Ph. D Dissertation, Harvard University, June 1987, Chapters 3-7. 
The momentum for this fundamental change was gained in the process of the revision of the Constitution, following the intense civil struggle for democratization, led by students, in June, and during the Presidential election campaign in late 1987. Although the campaign pledges of the DJP was less outspoken about the fundamental change than those of the three opposition parties were, as Presidential candidate Rho failed to win the election by a comfortable margin, ${ }^{122}$ the DJP and the elected President have nevertheless been put under enormous pressure to respect the national consensus (the need to readjust economic policy direction toward achieving greater economic and social equity) championed by the opposition parties. ${ }^{13)}$

Some recent developments may illustrate the point. As political voices of the so far alienated social groups such as the agricultural sector and the small and medium-size enterprises got stronger in the process of democratization, economic liberalization policies which have been undertaken "for the good of the national economy" (but relatively in disregard of the disproportionate burden falling on these weaker social groups), for example, met with strong resistance and legitimacy questions. ${ }^{14)}$ Particularly, the opening up of the domestic markets for foreign agricultural products, and the appreciation of the won, as a result of the accumulating bilateral trade surpluses and under the mounting pressure from the U.S., in particular, have been strongly resisted by these groups. The opposition parties, which have over the period of the election campaign declared them. selves, albeit in varying degrees, to represent these politically and socially alienated and disaffected groups, seek actively to protect the interest of these groups. As another example, deregulation of the financial sector is faltering because of its potentially negative

12) The DJP candidate, Rho Tae Woo, got 37 percent of the popular vote. The percentage of popular votes won by the DJP candidates in the National Assembly election remained at the same level.

13) The DJP and the government under President Rho have also displayed an fairly accommodating attitude. Upon inauguration, President Rho ordered to revise the Sixth Economic and Social Development Plan (1987 91) to reflect his campaign pledges in the Plan (for example, the upstaged development of agricultural and fisheries sector, the pursuit of balanced development of regions, the enlargement of social investment and welfare expenditure, and the privatization of public enterprises) and established two advisory committees: the Committee for Administrative Reform to realign the structure of government agencies and eliminate administrative wastes and inefficiencies and the Advisory Commission for Readjustment of Economic Structure to study major economic policy reform tasks ahead to be undertaken in the changing external and domestic policy environment.

14) For the analysis of the underlying forces of economic liberalization policies in Korea in the early 1980s, see Byung-Sun Choi, "Institutionalizing A Liberal Economic Order," op. cit., Chapters $5 \sim 6$. 
effects on the further concentration of economic power in the hands of big businesses, which have been mostly abhorred by the public, and because of the renewed need to channel more financial resources toward the so far neglected sectors of the economy. ${ }^{15}$

The implications of the recent political and institutional changes for the government. business relationship are quite clear. The influence of big business on the economic policy. making will diminish inevitably, leaving more space for the labor, small and medium-size businesses, and consumers. The revision of labor-related laws, the expanded application of the minimum wage system, an added emphasis on environmental protection and work safety, a stronger enforcement of the anti-monopoly and fair trade law, and the strengthening of consumer protection urge big businesses to take on greater social responsibility and to improve managerial practices. In all of these changes, it seems that the government wants to play a part as a neutral coordinator of conflicting interests, rather than as a biased arbitrator. But as the pendulum had been swung too far in the direction. of favoring big business, and in so far as the strong political and social forces to pull it back to the other extreme would not subside quickly, the returning pendulum is unlikely to stop nicely just where the government wants it do. ${ }^{16}$

On the other side, for the purpose of enhancing the interests of the so far alienated groups, the state agencies are required to adopt more analytical view of their clientele groups. In the past, some agencies such as the Ministry of Commerce and Industry, Finance, Construction, and the Environmental Protection Administration tended wittingly or unwittingly to side with big business in conformity with the direction of economic policy aimed at rapid economic growth, vastly in disregard of the interest of consumers or weaker sections of their clientele groups. By contrast, agencies like the Ministry of Agriculture, Forestry, and Fisheries and the Ministry of Labor failed to secure and protect the sectoral interest of farmers or workers in the process of industrialization. For this reason, the strongest protests and the most severe criticisms are being leveled against

15) Incidentally, it should be noticed that there exists a paradoxical trade-off between the policy objectives of economic liberalization and economic democratization, as the rationale for the need of each policy measure has different historical policy background and different implications for the economic policy problems at hand. The examples cited here may be the best cases in point illustrating the inherent conflict between the economic rationality and the political rationality.

16) On the reasons and the characteristics of radical policy shifts in many Latin American countries, see Albert O. Hirschman, Journeys Toward Progress: Studies of Economic Policy-Making in Latin America (New York: W.W. Norton \& Co., 1973), pp. 240-246. 
these two Ministries.

In order for these agencies to regain their institutional legitimacy, they must be able to secure confidence from the so far alienated or neglected sections of their constituent groups. To strengthen these groups' confidence in their policy actions, they must first be able to recover their policy initiatives in competent policy areas in which they have so far conceded willingly to the EPB in the name of the pursuit of "national" economic policy goals, or have been subjugated by the EPB unwillingly. Some examples would illuminate this point clearly. In the case of reopening beef imports, it has become clear that the government cannot decide in an authoritarian way whether and how much to reimport, as had been the case. ${ }^{17)}$ To persuade the cattle-raisers of the need to reopen beef imports, the government should prepare compensatory measures to prevent the farmers from being seriously hurt by them or provide the import-impacted sectors with assistance designed to help them turn to other business. In such process, only the Ministry of Agriculture, Forestry, and Fisheries can protect and represent the interest of the farmers legitimately and devise measures designed to alleviate their disproportionate burden. No other state agency, still less the EPB, can do this with the same degree of legitimacy and persuasiveness. ${ }^{18)}$

This, in turn, raises another legitimate and very important questions. If all other state agencies seek to pursue sectoral policy objectives and to secure institutional legitimacy, and the political and social climate changes in the direction of protecting and bolstering the interest of the so far alienated groups of society, how can the EPB coordinate related policies effectively and for the good of the economy as a whole? Could we expect that the EPB can deal with equity policy issues as much competently as it could with efficiency issues?

Needless to say, the tendencies of over-conforming to the overall economic policy goals in the past are resultants of the bureaucratic authoritarianism. To alleviate this bureaucratic tendency to conform and to recover legitimate interest representation function of these agencies, we may need to reconsider the existing economic policy-making and coordinating structure, built around the strong policy leadership by the President and the

17) The imports of beef has been stopped since 1986, after the domestic beef price fell dramatically due to excess supply. The government had encouraged farmers to raise cows in the preceding years.

18) For an illustrative example in the American context, see Roger B. Porter, The U.S, -U.S.S.R, Grain Agreement (Cambridge: Cambridge University Press, 1984). 
EPB. ${ }^{19)}$ This structure contributed, in no small measure, to this tendency. But when the merits of this structure, particularly the institutional characteristics of the EPB-its institutional autonomy and greater flexibility it enjoys in shifting econmic policy directions, and its greater scope and dimension of the mission in fulfilling the politico-economic visions of the central decisionmakers - can be adequately understood and skillfully exploited, and some corrective changes-such as the separation of operating functions from the EPB and the more constructive relationship between the Presidential economic secretary and the Deputy Prime Minister-are instituted in this structure, it can be even more important and valuable institutional asset in the changing and more democratized policy environment. ${ }^{20)}$

\section{B. State Control over the Financial Sector ${ }^{21)}$}

The Korean state has relied as its most powerful policy instrument on credit allocation to guide and control activities of generally highly-leveraged industries and business firms. ${ }^{221}$ As described by Mason et al. most vividly:

The Korean government has viewed control over the allocation of credit, both domestic and foreign, as an important element of economic and political policy. It has resisted repeated advice (mainly foreign) to let interest rates and competition among independent financial institutions determine the allocation of credit. (Few Korean businessmen have ever advocated such policy.) Instead, the government has kept loan interest rates below equilibrium levels and has intervened pervasively-although generally unofficially-in allocation decisions. The reasons for this appear to have been both economic and political: the credit instruments could be used to mobilize businessmen for major economic programs such as export promotion or development of the machinery and petrochemical industries, while on the political side they served to maintain control over, and cooperation from, the business community. All Korean businessmen, including the most powerful, have been aware of the need to stay on good terms with the government to assure continuing access to credit and to avoid harassment from the tax

19) For a detailed analysis, see Byung-Sun Choi, "The Structure of Economic Policy-Making Institutions in Korea and the Strategic Role of the Economic Planning Board (EPB)," Journal of Public Policy Studies, Vol. 2 (Spring 1988), Graduate School of Public Administration, Seoul National University, pp. 2-16.

20) Ibid.

21) On the general characteristics of financial sector in Korea and the strategic use of this sector by the government, see Mason et al., op. cit.; Jones and Sakong, op. cit.; and David Cole and Yung Chul Park, Financial Development in Korea, 1945 1978 (Cambridge, Mass.: Harvard University Press, 1983).

22) On the same point of argument, see Johnson, "Political Institutions," op. cit., pp. 73-75, 
officials. 23)

But under the public pressure and based on the lessons learned during the difficult period of economic readjustment in the early 1980 s that the direct and selective intervention by the government in the allocation of financial resources would only entail far more intricate problems, the government has undertaken a series of policy measures to liberalize the financial sector. Some examples are: the privatization of government-hold bank stocks, the internationalization of financial sector by allowing easier access of foreign banks to Korean market, and the encouragement of diversification and competition through facilitating the rapid growth of the non-bank financial intermediaries (NBFI) such as the short-term financing and investment companies, mutual funds and insurance companies. But it has been pointed out that the basic feature of the state control over the financial sector remains intact and the changes are to a considerable degree cosmetic. ${ }^{24)}$ Even after the privatization of government-controlled commercial banks, for example, the government has still retained its influence upon the appointment of bank managers and major operational decisions as to the management of bank resources.

Among major roadblocks before the financial sector liberalization, probably the most important is the existence of financially unhealthy firms (called Pulsilgióp) and the consequent huge amount of non-performing debts borne by the banks. ${ }^{25)}$ The accumulation of non-performing debts by the banks is, for the most part, the legacy of the economic and industrial policies (particularly the heavy and chemical industrialization) in the 1970s. ${ }^{26}$ ) To this group of firms added firms in the structurally depressed industries such as ocean shipping and foreign construction in the early 1980s. Judging that the financial problems of these firms could not be let unsolved indefinitely, the government launched a massive "rationalization" effort in six episodes between May 1986 and February 1988. ${ }^{27}$ )

23) Mason et al., op. cit., pp. 336-337.

24) Chalmers Johnson observed that "the changing relations between the public and private sectors are, in my view, cyclical and not linear; the logic of the systems [the government-business relationship in Japan, Korea, and Taiwan (explanation offered by the author)] remains unaltered even though their particular structures have considerable flexibility." See Johnson, "Political Institutions," op. cit., p. 72.

25) As of July 1988, total amount of non-performing assets, which should be written off by default, owned by 7 nation-wide commercial banks and 17 local banks reached 250 billion won (about $3.3 \$$ billion, estimated at 750 won: $1 \$$ ). See Maeil Kyungje Shinmun, July 23, 1988.

26) For a detailed analysis, see Choi, "Institutionalizing A Liberal Economic Order," op. cit., Chapter 3.

27) In selecting firms to be subjected to industrial rationalization, the government used the 
Among 78 firms, subjected to rationalization, 57 firms changed hands, 19 merged, and the remaining 2 were liquidated. Total financial assistance (in the form of rescheduling the payments of interest and principal and the new credit called "seed money") and tax benefits, provided in the rationalization process, amounted to 11,418 billion won (about $14.27 \$$ billion, estimated at 800 won: $1 \$) .{ }^{28)}$ In so far as the government is, in no small measure, to blame for the accumulation of non-performing debts, it cannot shun its responsibility. In addition, because of the problem of "moral hazards" on the part of the commercial banks, the government cannot abdicate its control over the financial system entirely. ${ }^{29)}$

The recent political and economic changes seen in the above section bear greatly upon the process of liberalizing the financial sector. First, as political democratization proceeds, the politics-industry nexus(chüngkyüngyuch'ak) came under frontal attack by the opposition parties and the so far alienated, minor groups of society, and the issue of insulating the financial system from illegal and illegitimate political influences has become a matter of great public concern. ${ }^{30}$ ) Second, it has been abhorred that the bank credit has been channeled disproportionately greatly to major chaebol groups. While the thirty largest chaebol groups ( 676 firms) accounted for 40.2 percent of manufacturing sales, 41.3 percent of manufacturing exports, and 17.6 percent of manufacturing employment in $1984,{ }^{31)}$ the bank loans provided to them amounted, as of June 1988, to 19,704 billion

following somewhat ambiguous criteria: 1) structurally depressed industries necessitating industrial restructuring; 2) minor lines of businesses under the control of chaebol needing streamlining; and 3) firms continuously accumulating non-performing debts.

28) Finance Minister's report to the National Assembly, Maeil Kyungje Shinmun, July 21, 1988. In this calculation, special loan by the Bank of Korea to commercial banks is included.

29) Moral hazards refers to the general tendency of neglecting to exercise an usual amount of caution, duly exercised otherwise. Here it refers to a tendency of commercial banks to fail to exercise due amount of effort to decrease the size of non-performing debts and the operational loss caused by them in the expectation that they can rely upon the government anyway.

30) The government's rationalization efforts, particularly the process of selecting new owners of the rationalized firms, is subject to great public suspicion in that it facilitated, in effect, a further concentration of economic power in the hands of businessmen in particular allegiance to the Fifth Republic.

31) Kyu Uk Lee, “Kyǒngjeryukjipjungǔi Hyunhwanggwa Kongjŏnggoraejŏngch'aek (The current state of economic power concentration and the fair trade policy)," KDI, 1988. The corresponding figures in 1977 were $34.1 \%, 38.5 \%$, and $20.5 \%$, respectively, indicating that the economic concentration has been intensifying, while its contribution to employment declining. Unfortunately, no statistics is available to estimate the importance of the 30 largest chaebol groups in the national production, export, and employment. But we can derive rough estimates by multiplying these figures by the share of manufacturing sector in the GNP, export, and ẹployment, respectively. 
won, 26.9 percent of the total. ${ }^{32)}$ In addition to bank loans and loan guarantees, the chaebol groups are found to have taken up a lion's share of the financing facilities of the non-bank financial intermediaries (NBFI) as well. ${ }^{33)}$ And it has been made public by the Fair Trade Committee that the chacbol groups have been multiplying the number of firms under their control mainly through mutual stock investment, which is prohibited under the Anti-Monopoly and Fair Trade Law. ${ }^{34)}$

Under these circumstances, the government (the Bank Supervisory Board) has since April this year instituted a "credit management basket system for chaebol groups," which set the upper limit of bank loans and bank credit (loan+loan guarantee) to be offered to the thirty largest chaebol groups at the rates where they stood as of the end of October 1987, and has been putting pressure on chaebol groups to reduce their reliance on the bank credit by way of financing directly from the beoming stock market. ${ }^{35}$ The government has also sought ways to increase the availability of financial resources for the small and medium-size enterprises, agricultural sector, and other so far alienated sectors of the economy. The plan to establish another Small and Medium-Size Enterprise Bank, to make the special funds for these sectors more easily accessible, and to reorganize the structure of Agricultural Cooperatives in a more democratic way are signs of change in this direction. As such, the need to ensure the use of financial resources to be more equitable among potential beneficiaries seems to invite a renewed government intervention in the financial sector, obstructing the progress of financial sector liberalization. ${ }^{36}$

Out of the paramount need to insulate the financial sector from illegitimate political

32) In this calculation, the credit by the Small and Medium-Sized Enterprise Bank, National Bank, and the Agricultural, Fisheries, and Livestock Cooperatives, which do not usually make bank loans to big business, is not included. The corresponding share of the five largest chaebol groups amounted to 14.6 percent. See Dong-A Ilbo, September 3, 1988. The ratio of bank credit (except loan guarantee) to total assets of the thirty largest chaebol groups reached 22.3 percent on average, ranging from 45.6 percent of Hanil Synthetic Fiber to 7 percent of Lotte. For more detail, see Maeil Kyungje Shinmun, July 19, 1988.

33) As of June 1888, 30.6 percent of the total commercial paper (CP) discounts was made by the 19 largest chaebol groups. See Maeil Kyungje Shinmun, August 2, 1988.

34) Mutual investment refers to a fictitious (just on paper) movement of investment fund between firms. As of the end of March, 1988, the amount of mutual investment by the forty largest chaebol groups amounted to 284.8 billion won. See Dong-A Ilbo, July 20, 1988.

35) As a result, the share of bank loan by the thirty largest chaebol groups declined from 25.65 percent in October 1987 to 23.19 percent in June 1988. The corresponding ratios for the largest five chaebol groups fell 15.23 percent to 13.52 percent. See Dong-A Ilbo, September $3,1988$.

36) Once again, we can confirm a trade-off between economic liberalization and ecconomic dẹmocratization, 
influence and excessive bureaucratic intervention, arose the recent controversy over the independence of the Bank of Korea(BOK), the central bank in Korea. Taking advantage of the political climate changing in its favor and being inspired by the general support of the three opposition parties, ${ }^{37)}$ the $\mathrm{BOK}$ has argued that it should recover its preeminent status as the central bank that it had enjoyed before the revision of the BOK law in 1962, and that the governor of the BOK, rather than the Finance Minister, should chair the Financial and Monetary Board, officially the highest authority over monetary and financial policy matters. ${ }^{39)}$ Recognizing the need to respond to such pressure in one way or another, ${ }^{39}$ the Ministry of Finance has sought to separate the role of the Board, as the highest monetary and financial policy-making authority, from the BOK.40) But in view of the public nature of licensing and supervising bank operations, the MOF has insisted that the supervisory responsibility, currently within the jurisdiction of the BOK, should be held by the MOF. Of course, the BOK has strongly resisted to the MOF's intention. ${ }^{41)}$ The stance of the financial community is split depending on their own competitive position in the sector.

Whatever result may obtain from this controversy in the process of revising the Bank of Korea Law between the government (MOF), the DJP, the opposition parties, and the BOK and other interest groups concerned, it is quite certain that a greater degree of autonomy will be allowed to the financial sector, and that, as a result, the importance of credit allocation as effective political and economic policy instrument, as seen in the above

37) The position of the opposition parties retreated from their original position, released around the time of the Constitutional revision in 1987, and has been drawing closer, over time, to that of the DJP and the government (MOF). On the coordinated position on the issue of the three opposition parties, see Hangkuk Kyungje Shinmun, November 9, 1988.

38) Since 1961, Finance Minister has presided over the Committee and exercised his authority to seek the second opinion of the Committee's decision, with the result of relegating the Committee to a status of operational committee and the BOK to a status of an implementing agency.

39) For a political-economic analysis of the reluctance to undertake financial sector liberalization on the part of the MOF, see Choi, "Institutionalizing A Liberal Economic Order," op. cit., Chapter 6; and Byung Kyun Min, "Keumyungsanopui Chayulhwa (Financial sector liberalization)" in Kyungjeminjuhwaui Kibongusang (Basic Ideas for Economic Democratization), Korea Economic Institute, 1988, pp. 347-383.

40) Under this scheme, the chairman of the Financial and Monetary Board would be named by the President among Board members and upon their nomination and Finance Minister's concurrence.

41) Although the supervisory authority has fallen within the jurisdiction of the BOK, the MOF has had greater and direct influence over the Bank Supervisory Board. Admittedly, therefore, this has become the core of the controversy, and the intense institutional struggle for greater power and authority between the MOF and the BOK is being fought on. 
citation, will be phased down. The implications of this institutional change for the future government-business relationship are profound.

\section{Labor Relations}

Tranquility has long characterized the labor relations in Korea. And it seemed particularly true from the Western viewpoint. ${ }^{42)}$ But the repeated eruption of economy-wide labor strikes and disputes, whenever a state of political power vacuum appeared, shows most eloquently that the seemingly tranquil labor relations has never been spontaneous, but it represents an element of the repressive and authoritarian rule. The sharp rise of labor disputes in the aftermath of the April 19 Student Revolution in 1960, the assassination of President Park Chung Hee in October 26, 1979, and the "June 29 Declaration" by Rho Tae Woo in 1987 are good examples.

Labor strikes and disputes in the wake of the "June 29 Declaration" revealed most vividly the changing character of labor relations in Korea. First of all, the number of labor disputes for four months from June 29 to October reached 3,567 , about 1.8 times as great as those recorded for the period of 12 years between 1975 and June 1987. ${ }^{43}$ ) They were more frequent and fiercely fought on in larger firms (employing more than 100 workers) than smaller ones, and in manufacturing, mining, and transportation industries than others. Major causes of labor disputes were the wage increase (72.0\%), the improvement of working conditions (15.1\%), and the failure to reach collective bargaining or unfair labor practices $(5,0 \%) .{ }^{44)}$ Major patterns of labor disputes were strikes $(32.7 \%)$ and sits-in $(64.7 \%) .{ }^{45}$ The average rate of wage increase achieved was 13.5 percent, compared to 29.1 percent of the average rate of requests. ${ }^{46)}$ And the actual rate of wage increase was higher in firms without labor unions and small and mediumsize enterprises, indicating that labor disputes contributed to shrink wage gaps in similar industrial sectors. ${ }^{47)}$

Second, probably the most significant, is the sharp increase in the number of labor

42) Johnson, "Political Institutions," op. cit., pp. 75-77.

43) The Ministry of Labor, “Ch'oegeun Rosabunkyup'yŭnggawa Daeŭngbangan (Evaluation of recent labor disputes and countermeasures)," October 1987.

44) Ibid.

45) Ibid.

46) Korea Council of Managers, “Ch'oekeun Rosabunkyu Chonghapbunsōk (Comprehensive analysis of recent labor disputes)," September 28, 1987.

47) Chae Won Kim, "Koyongjeundaemit Saeroun Rosagwangwejöngripbanghyang (Employment growth and a new direction for the establishment of labor relations), " in Kyungjeminjuhwa, op. cit., pp. 188-191. 
unions and the ratio of unionization. The number of labor unions jumped by 57.3 percent from 2,263 in 1986 to 3,559 in October 1987, and the ratio of unionization increased from 12.9 percent (939 thousand) to 15 percent $\left(1,275\right.$ thousand) in the same period. ${ }^{48)}$ This might necessarily follow from the fact that the labor opposition was part of the driving forces in disavowing and deposing the repressive political regime, and the labor having experienced their collective power began to take a more aggressive posture. ${ }^{49}$ It was this unprecedented aggressiveness on the part of the labor that enabled them to secure a surrender by the several major chaebol group companies like Hyundai to admit labor unions in their companies. Behind this aggressiveness was, in part, an infiltration of the socalled "foreign forces," a group of students and religious activists, who were highly conscious of the labor problems and tried to arouse self-awareness of workers. ${ }^{50}$ Their strategy was to press for unacceptably high wage increase, overthrow the existing leadership of labor unions, and to lead the labor movement aggressively in their own initiatives. ${ }^{51)}$

However important was the influence of the "foreign forces," the labor unrest seems to have taken root deeply in the change of political and economic conditions. As is commonly pointed out, many of the causes of labor unrest are not of cyclical but structural nature: 1) political democratization; 2) the heightening social discontent about the widening income disparity; 3) neglect of labor welfare incompatible with the rising labor consciousness; 4) the lack of confidence between employers and employees; 5) wage gap between white and blue collar workers; 6) the inadequacy of labor-related laws; 7) internal and organizational problems of labor unions; 8) and the traditional bias against labor unions, particularly their political activities. ${ }^{52)}$

In the wake of June-October labor disputes and under the enormous pressure by the labor unions and the opposition parties, and also partly in response to the U.S. threat to restrict Korean exports to the American market for the reason of the infringement upon labor rights in exporting countries, as reflected more clearly in the process of legislating

48) Ibid.

49) See Yu Kun Shin, Han'gukŭi Kyðngyð̆ngnosakwangwe (Labor Management Relations in Korea) (Seoul: Korea Chamber of Commerce and Industry, 1988), pp.32-34.

50) Ibid., pp. 37-38.

51) Kim, "Koyonggeungdae" op. cit. The fact that out of 3,567 firms having experienced labor disputes, 57.3 percent of firms had had labor unions, and most of these labor unions were disavowed as government-patronized may be indicative.

52) Ibid., pp. 195-196. 
the omnibus trade bill of 1988 , the Korean government revised the labor-related laws in November 1987. Under the revised Labor Union Law, any type of labor union-enterprise union, regional union, industrial union, and confederate union-is allowed; the formalities required for the establishment of labor unions is greatly simplified; various kinds of government intervention in the operation of labor unions is greatly reduced; and the union-shop system is partly recognized. Under the revised Labor Dispute Settlement Law, voluntary settlement procedure is allowed and the cooling-off period is shortened, but, the third party intervention is still not permitted. ${ }^{53)}$ As seen above, in addition to the revision of the labor-related laws, the government has already promised that it would refrain from intervening labor disputes in the interest of business and maintain hands-off policy to the extent possible. All these changes indicate that the era of the governmentimposed, tranquil labor relations is coming to a close.

\section{Implications for the Government-Business Relationship and the Economy's Performance}

As pointed out earlier, countries having keen interest in the government-business relationship in Japan, Korea, and Taiwan are those that have brought the democratic free enterprise system in full bloom but have long begun to experience deteriorating competitiveness in the world market and to face institutional difficulties in grappling with many complex domestic economic and social problems. Political economists in the U.S., in particular, pointed out that such persistent problems in the country as low economic growth, relatively high unemployment and consequently high social expenditure, deteriorating quality of education, increasing crime, environmental problems, delayed industrial restructuring, and the ever-expanding protectionist sentiments owe greatly to the extreme fragmentation of governmental authority, the antagonistic and adversarial relationship between the government (and the public) and business, and the political influence of many well-organized and active special interest groups in the policy-making process. ${ }^{54}$

53) For the analysis of the contents of revised labor-related laws, see Korea Chamber of Commerce and Industry, 1990nyondae Han'gukrosagwangwerti Paljonbanghyaog (Directions of the Development of Labor Relations in the 1990s, pp.116-125; and for the process of revising the laws and the positions advocated by concerned parties, see Kim, Ibid., pp. 229-241.

54) For representative literature, see John T. Dunlop (ed.), Business and Public Policy (Cambridge, Mass.: Harvard University Press, 1980); Robert B. Relch, The Next American 
Admitting that the preservation of check and balance by the division of governmental power, emphasis on social responsibility of free enterprises, and the broader participation of diverse interest groups in the public policy-making process are invaluable institutional virtues of the democretic and pluralistic society, such researchers emphasize that, when these virtues are overly valued, they inevitably exact a high price in terms of systemic adaptability to rapidly changing domestic and external conditions and efficiency in managing the governmental problems.

The current studies of government-business relationship in the U.S. seem to focus on the following issues: (1) What institutional change in governmental structure and functions is needed for swifter and more effective adjustment to the rapidly changing competitive conditions outside and for the efficient solution of domestic problems? (2) How can more constructive and cooperative relations between the government and business be secured? (3) How should the public policy-making process be modified to guard against the predominance of special group interests? (4) What are the institutional norm and arrangements according to which the internal organization and methods of interaction of the societal groups (particulary labor unions and business associations) should be restructured? (5) How can negative effects which may result from a more collaborative relationship between the government and business(corruption, for example) be effectively insured against?

No doubt, these issues are particularly germane to American situation and reflect the unique historical and institutional tradition and custom of the U.S. Nevertheless, these issues may well be considered to be relevant for any types of politico-economic system, for the key issues in studies of government-business relationship are: how to overcome systemic tension and conflicts intrinsic in any politico-economic system, and how to strengthen systemic adaptability to the changing environments. As we have thus far examined, the progress of political and economic democratization in Korea increasingly turn the above questions into legitimate and particularly relevant questions to be asked in Korea, too.

At the present time, the potential costs of political and economic democratization to the Korean economy have not been materialized, except the case of wage hikes prompted by collective labor actions last year. ${ }^{55)}$ Neither can any one correctly project the magnitude Frontier (New York: Times Books, 1983); and Lester C. Thurow, The Zero-Sum Society (New York: Basic Books, 1980).

55) Although the potential conflict between economic democratization and liberalization has been 
of the costs, nor can one confidently weigh the potential trade-offs between more demo. cratized society and the loss of the continued economic growth momentum, if they are incompatible at all. But it should be noticed that the currently strong economy is certainly obscuring the potential costs of political and economic democratization. The political and social climate also tends to prohibit people from discussing them openly.

Given that the policy environment is rapidly changing and becoming increasingly uncertain, what is most important is the sense of direction of institutional change and the political accountability. First of all, it is very important at this stage that the political leaders have a clear vision which politico-economic order, that of the U.S. or Japan, among others, that Korea should be pursuing. Second, responsible political actors and the state agencies must and can stand squarely against this public indifference and the tendency to over-conform. ${ }^{56)}$

\section{Conclusion}

In this study, I have sought to examine the driving forces behind and the progress toward political and economic democratization in Korea and evaluate its impact on the government-business relationship and its potential costs to economic performance. As many of these changes are still burgeoning, and as no concrete evidence or empirical analysis is yet available, no definite evaluation is provided. In the process of trying to analyze the nature and direction of the recent institutional changes based on the major aspects of the current studies of the government-business relationship-state economic policy-making structure, the state control over the financial sector, labor relations, the economic power of chaebol groups, and so on-however, this article could help identify the distinctive characteristics of such changes and provide a new perspective from which the torrents of

stressed in this study, economic democratization can contribute greatly to the improvement of economic efficiency. For example, wage increase would induce efforts of businessmen to increase the productivity to offset it. A more equitable allocation of financial resources may lead to a more efficient use of them. But what this study tries to focus on is their further effect on unemployment, inflation, and economic and export growth.

56) A recent episode surrounding the issue of determining the government purchase price of rice may be illuminating. It is told that the Deputy Prime Minister, responsible for the economy's overall performance and inflation, in particular, quit the room, in which the governmentruling party conference deliberating the issue was held, saying outragedly that if you politicians in the ruling party also insist upon a higher rate of rice price increase than the government suggests, how and by whom can the inflationary pressure be effectively contained and who would hold the responsibility for the policy failure and its political consequences?" 
the recent political and economic changes, still appearing on stream, can be more intelligibly analyzed in the future.

This study has also tried to direct attention to the paradoxical trade-offs working in all of the humam political and social institutions. That is, the underlying assumption of this study has been that no human political and social institution can be perfect: the fullblown democratic, free enterprise systems suffer generally from the slack of efficiency, while the authoritarian market economies suffer from the lack of political legitimacy.

\section{References}

Ahn, Byǒng Yŏng, “Ch'aejewigiǔi Keukbokgwa Chŏngch'aekgyǒljŏngŭi Soaeshin(Overcoming the systemic crisis and innovating the policy-making process)," paper presented to the International Conference on Public Administration for the Mature Democratic Society, August 24, 1988.

Choi, Byung-Sun, "Institutionalizing A Liberal Economic Order in Korea: The Strategic Management of Economic Change," Ph. D Dissertation, Harvard University, June 1987. Choi, Byung-Sun, "The Structure of Economic Policy-Making Institutions in Korea and the Strategic Role of the Economic Planning Board (EPB)," Journal of Public Policy Studies, Vol. 2 (Spring 1988), Graduate School of Public Administration, Seoul National University.

Cole, David C. and Park, Yung Chul, Financial Development in Korea, 1945 1978 (Cambridge, Mass.: Harvard University Press, 1983).

Collier, David (ed.), The New Authoritarianism in Latin America (Princeton: Princeton University Press, 1982).

Cummings, Bruce, "The Origins and Development of the Northeast Asian Political Economy: Industrial Sectors, Product Cycles, and Political Consequences," in International Organization (Winter 1984), Vol. 38, No. 1.

Dunlop, John T. (ed.), Business and Public Policy (Cambridge, Mass.: Harvard University Press, 1980).

Evans, Peter et al. (eds.), Bringing the State Back In(Cambridge: Cambridge University Press, 1985).

Goldthorpe, John H. (ed.), Order and Confict in Contemporary Capitalism: Studies in the Political Economy of Western European Nations (Oxford: Clarendon Press, 1984). 
Hall, Peter, Goverwing the Economy: The Politics of State Intervention in Britain and France (New York: Oxford University Press, 1986).

Hall, Peter, "Patterns of Economic Policy: An Organizational Approach," in Stephen Bornstein et al. (eds.), The State in Capitalist Europe(London: George Allen \& Unwin, 1984).

Hirschman, Albert O., Journeys Toward Progress: Studies of Economic Policy-Making in Latin America (New York: W.W. Norton \& Co., 1973).

Japan Economic Institute of America, "Japan's Industrial Policies," Monograph, Washington, D.C., April 1984, pp. 3-6.

Jones. Leroy P. and Sakong, Il, Government Business, and Entrepreneurship in Economic Development: the Korean Case (Cambridge, Mass.: Harvard University Press, 1980). Johnson, Chalmers, MITI and the Japanese Miracle (Stanford: Stanford University Press, 1982).

, "Political Institutions and Economic Performance: The GovernmentBusiness Relationship in Japan, South Korea. and Taiwan," in Robert A. Scalapino et al.(eds.), Asian Economic Development and Future (Berkeley: University of California Press, 1985).

Katzenstein, Peter J., Small States in World Markets (Ithaca: Cornell University Press, 1985).

- Between Porver and Plenty: Foreign Economic Policies of Advanced Industrial States (Madison: University of Wisconsin Press, 1984).

Kim, Chae Won, "Koyongjeundaemit Saeroun Rosagwangwejŏngripbanghyang (Employment growth and a new direction for the establishment of labor relations)," in Kyöngjeminjuhwaǔi Kibongusang (Basic Ideas for Economic Democratization), Korea Economic Institute, 1988).

Korea Chamber of Commerce and Industry, 1990nyǒndae Han'qukrosaquangweŭi Paljǒnbanghyang (Directions of the Development of Labor Relations in the 1990s, 1988.

Korea Council of Managers, “Ch'oekeun Rosabunkyu Chonghapbunsǒk (Comprehensive analysis of recent labor disputes)," September 28, 1987.

Lee, Kyu Uk, “Kyŏngjeryukjipjungŭi Hyunhwanggwa Kongjŏnggŏraejŏngch’aek (The current state of economic power concentration and the fair trade policy)," KDI, 1988.

Lim, Youngil, Government Policy and Private Enterprise: Korean Experience in Industrialization (Berkeley: University of California Press, 1981). 
Lindblom, Charles E., Politics and Markets: The World's Political-Economic Systems (New York: Basic Books, 1977). , The Policy-Making Process (Englewood Cliffs, New Jersey:

Prentice-Hall, Inc., 1968).

Magaziner, Ira Magaziner and Reich, Robert B., Minding America's Business(New York: Law \& Business, Inc., 1982).

Mason, Edward et al., The Economic and Social Modernization of the Republic of Korea (Cambridge, Mass.: Harvard University Press, 1980).

Min, Byung Kyun, "Keumyungsanŏpŭi Chayulhwa (Financial sector liqeralization)" in Kyöngjeminjuhwaüi Kibongusang (Basic Ideas for Economic Democratization), Korea Economic Institute, 1988).

Ministry of Labor, "Ch'oegeun Rosabunkyup'yunggawa Daeungbangan (Evaluation of recent labor disputes and countermeasures)," October 1987.

Porter, Roger B., The U.S.-U.S.S.R. Grain Agreement (Cambridge:Cambridge University Press, 1984).

Reich, Robert B., The Next American Frontier (New York: Times Books, 1983).

Shin, Yu Kun, Han'gukŭi Kyöngnosakwangwe (Labor Management Relations in Korea) (Seoul: Korea Chamber of Commerce and Industry, 1988).

Thurow, Lester C., The Zero-Sum Society (New York: Basic Books, 1980).

Turner, Louis \& McMullen, Neil, The Newly Industrializing Countries: Trade and Adjustment (New York: George Allen \& Unwin, 1982).

Vogel, Ezra F., Japan As Number One (Cambridge, Mass.: Harvard University Press, 1979).

Yu, Hoon and Choi, Byung-Sun, "Keumhu Kyŏngjejayulhwaŭi Chuyogwajewa Ch'ujinch'eje Kaesŏnbangan (Major Issues of Economic Liberalization Ahead and Schemes for Furthering its Progress)," Korea Development Institute, December 1987. 